\title{
Increasing penicillin resistance in pneumococci isolated from cerebrospinal fluid samples: Fifteen-year experience from a teaching hospital
}

\author{
Filiz Pehlivanoğlu, Gönül Şengöz, Sevtap Gürsoy \\ Department of Clinical Microbiology and Infectious Diseases, Haseki Training and Research Hospital, Istanbul, Turkey.
}

\begin{abstract}
Objective: There have been prominent changes in evaluation of resistance patterns of pneumococci and breakpoint values in recent years. We aimed to investigate the penicillin sensitivity of pneumococcal strains isolated from the cerebrospinal fluid specimens between the years 1997-2011 in our hospital and determine the MIC values under the light of these changes.
\end{abstract}

Methods: Identification of pneumococci was made with conventional methods in patients with meningitis. MIC values for penicillin $\mathrm{G}$ were investigated by $\mathrm{E}$ test method in all strains. MIC values of pneumococci strains were evaluated according to values determined by CLSI for meningitis isolates in 2008.

Results: A total of 57 strains were investigated in this study. The MIC range for penicillin was $0.016-0.75 \mu \mathrm{g} / \mathrm{ml}$ in $S$. pneumoniae strains. Seventy five percent of the strains were sensitive and eight strains (14\%) had resistance. MIC50 value was sensitive, and a MIC90 value was resistant. The first resistant strain was detected in 2000, and three strains were resistant in the last year. When examined over the years increased resistance was $5.3 \%$ in the first five-year period seems to be $28.6 \%$ in the last five-year period.

Conclusions: Knowledge on penicillin resistance patterns and surveillance is very important in the empirical treatment in pneumococcal meningitis. J Microbiol Infect Dis 2014; 4(4): 136-140

Key words: S. pneumoniae, penicillin resistance, CSF, breakpoint.

\section{BOS'tan izole edilen pnömokok suşlarında penisilin direncinin artışı: Bir eğitim hastanesinden 15 yıllık tecrübe}

\section{ÖZET}

Amaç: Son yıllarda pnömokok bakterilerine direncin değerlendirilmesinde ve eşik değerlerinde büyük değişimler meydana geldi. Bu değişimler ışığında hastanemizde 1997-2011 yıllarında beyin omurilik sıvısı (BOS) örneklerinden izole edilen pnömokok suşlarında penisilin duyarlılıklarındaki değişimin araştıııması amaçlandı.

Yöntemler: Tümü menenjitli hastalardan izole edilen pnömokokların tanımlamaları konvansiyonel yöntemlerle yapıldı. Tüm suşlarda penisilin G için MiK değerleri E test yöntemiyle araştıııldı. 2008 yılından itibaren pnömokoklarda penisilin MiK sınır değerleri, CLSI rehberine göre BOS izolatlarında $\leq 0,06 \mu \mathrm{g} / \mathrm{ml}$ duyarlı ve $\geq 0,12 \mu \mathrm{g} / \mathrm{ml}$ dirençli olarak değiştirildi.

Bulgular: Çalışmanın kapsadığı dönemde toplam 57 suş araştırmaya dahil edildi. S. pneumoniae suşlarında, penisilin için MiK aralığı 0,016-0,75 $\mu \mathrm{g} / \mathrm{ml}$ arasında bulundu. Suşların \%75'i duyarlı, sekizi (\%14) dirençli olarak tespit edildi. Mik50 değeri duyarlı, Mik90 değeri ise dirençli olarak saptandı. İlk dirençli suş 2000 yılında saptanırken son yıl ise suşların üçü dirençli bulundu. Yıllar içinde direnç artışı irdelendiğinde ilk beş yıllık periyotta \%5,3 iken son beş yıllık periyotta \%28,6 olduğu görülmektedir.

Sonuç: Pnömokok menenjitlerinde penisilin direncinin bilinmesi ve takip edilmesi ampirik tedavi açısından büyük önem taşımaktadır.

Anahtar kelimeler: S. pneumoniae, penisilin direnci, BOS, sınır değer. 


\section{INTRODUCTION}

Streptococcus pneumoniae which was first described in 1880, is still an important cause of mortality and morbidity globally. Pneumococcal meningitis is a severe form of meningitis with devastating sequela and frequent recurrences, as well as being a high-risk disease particularly for patients with diabetes or other diseases that weaken the immune system, with a mortality that is nearly equal to that in the pre-antibiotic era. ${ }^{1}$

Although introduction of penicillin into clinical practice opened a new epoch in the treatment of diseases caused by $S$. pneumoniae, the first resistant isolate was reported in 1967, and other reports of resistant strains followed this from all around the world. ${ }^{2}$ Until 1980, this resistance was both rare and moderate without clinical failure in penicillin treatment. The epidemics in 1980s with resistant $S$. pneumoniae strains and high-levels of resistance with clinical treatment failures brought this issue into the light once again. Especially the high levels of resistance detected in some regions of the world have brought attentions to these severe, life-threatening infections. Great changes have occurred in resistance patterns of pneumococci and break point values in recent years. MIC values of $S$. pneumoniae strains isolated from the cerebrospinal fluid (CSF) in the last 15 years were evaluated according to new criteria in the present study.

\section{METHODS}

Penicillin resistance of $\mathrm{S}$. pneumonia was evaluated retrospectively in Haseki Training and Research Hospital between 1997 and 2011. CSF samples were cultured in blood culture test tubes (BacT Alert BioMerieux, France) and chocolate agar culture media and incubated at $37^{\circ} \mathrm{C}$ in $5 \% \mathrm{CO}_{2}$ containing incubator overnight. Identification of the colonies were done according to colony morphology, Gram staining and optochin sensitivity. Colonies with lancet-shaped Gram-positive cocci, causing a-hemolysis at $5 \%$ sheep blood agar culture media, sensitive to optochin and dissolving in bile were considered as S. pneumoniae. MIC values for penicillin were determined with $E$ test (AB Biodisk, Solna, Sweden). These MIC values were re-evaluated according to new criteria determined by Clinical and Laboratory Standards Institute (CLSI) for meningitis isolates $(\leq 0.06 \mu \mathrm{g} / \mathrm{ml}$ sensitive and $\geq 0.12 \mu \mathrm{g} / \mathrm{ml}$ resistant) in 2008. ${ }^{3}$

\section{RESULTS}

A total of 57 pneumococci were isolated from CSF samples in the Microbiology Laboratory. The yearly distribution of $S$. pneumoniae isolates are shown in Figure 1. Two peaks of isolated pneumococci strains, one in 2000 and the other in 2002 are observed.

MIC range for penicillin was determined as $0.016-0.75 \mu \mathrm{g} / \mathrm{ml}$ (Table 1). Eight strains were resistant to penicillin (14\%) and 44 strains $(77.1 \%)$ were sensitive (Figure 1). Five strains $(8.7 \%)$ were between the ranges for sensitive and resistant. The first resistant strain was isolated in the year 2000. A MIC90 value of $0.19 \mu \mathrm{g} / \mathrm{ml}$ was found and a MIC50 value of $0,016 \mu \mathrm{g} / \mathrm{ml}$ was detected in all isolates. When examined over the years increased resistance was $5.3 \%$ in the first five-year period seems to be $28.6 \%$ in the last five-year period (Figure 2).

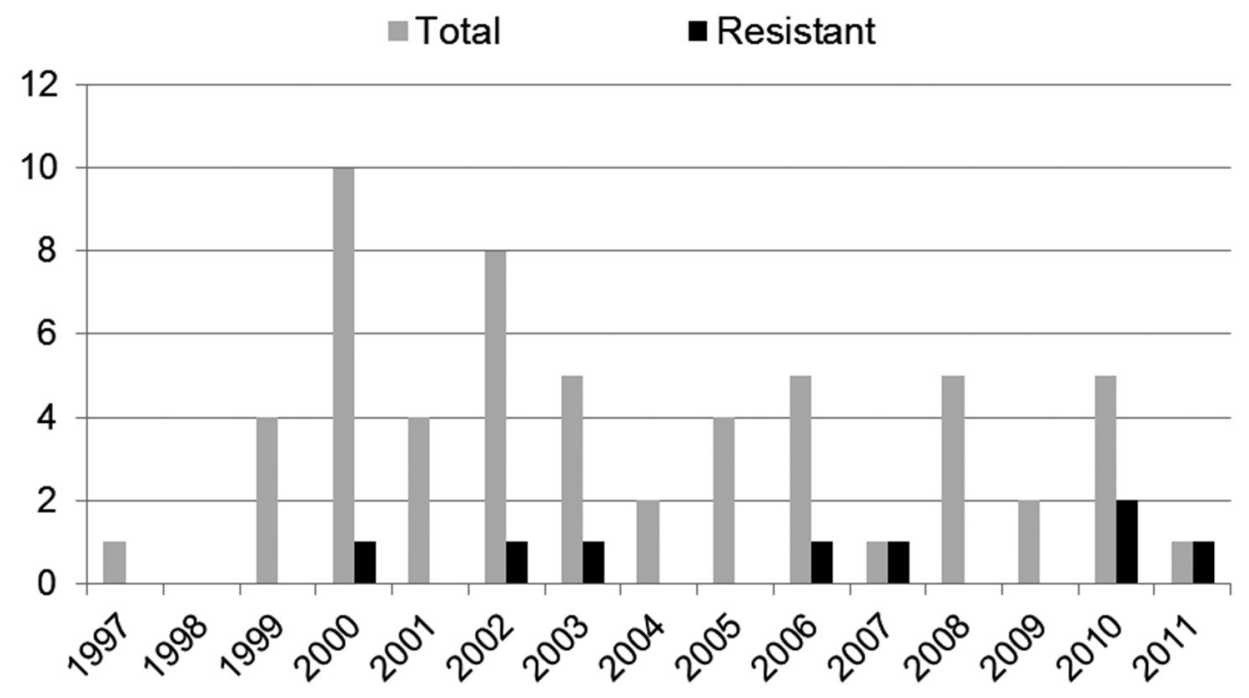

Figure 1. Yearly distribution of total and resistant S. pneumoniae strains isolated from the CSF. 


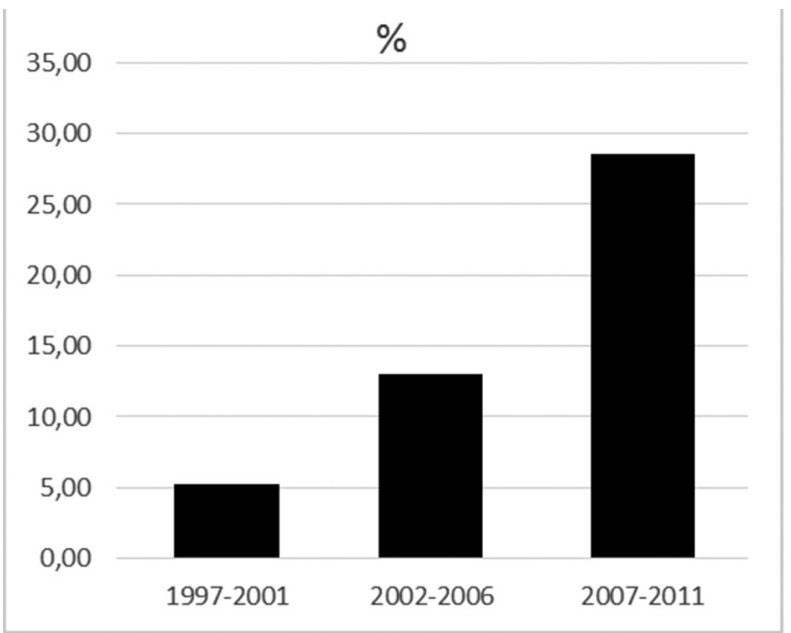

Figure 2. Resistance increase in the 5-year period

Table 1. Distribution of MIC values of pneumococci strains for penicillin $\mathrm{G}$

\begin{tabular}{cc}
\hline $\mathrm{MIC} \mu \mathrm{g} / \mathrm{ml}$ & $\mathrm{N}(\%)$ \\
\hline 0.016 & $37(64.9)$ \\
0.023 & $4(7.0)$ \\
0.032 & $3(5.3)$ \\
0.047 & $1(1.8)$ \\
0.064 & $1(1.8)$ \\
0.094 & $3(5.3)$ \\
0.125 & $1(1.8)$ \\
0.19 & $2(3.5)$ \\
0.25 & $2(3.5)$ \\
0.38 & $2(3.5)$ \\
0.75 & $1(1.8)$ \\
Total & $57(100.0)$ \\
\hline
\end{tabular}

\section{DISCUSSION}

The sole natural reservoir of $S$. pneumoniae is the human nasopharynx. All children become colonized by one or more strains in the first year of their lives and thus become carriers. It is reported that $50 \%$ of two-month old infants are colonized in South India, and $30 \%$ of six-month old infants are carriers in South Africa. ${ }^{4}$

Penicillin resistance of $S$. pneumoniae is a resistance caused by a change in the structure of penicillin-binding proteins. Therapeutic strategies should be carefully chosen in the future, under the light of the fact that resistance develops as a result of inappropriate antibiotic use. CLSI have changed the standards for MIC values in 2008 for S. pneu- moniae in vitro antibiotic sensitivity tests. Before 2008, MIC values of pneumococci strains for penicillin $\mathrm{G}$ were as follows: $\leq 0.06 \mu \mathrm{g} / \mathrm{ml}$ susceptible, $0.12-1 \mu \mathrm{g} / \mathrm{ml}$ intermediate and $\geq 2 \mu \mathrm{g} / \mathrm{ml}$ resistant. ${ }^{5}$ In 2008, the samples used in the evaluation were classified as meningitis isolates and nonmeningitis isolates, and a value of $\leq 0.06 \mu \mathrm{g} / \mathrm{ml}$ was used for susceptible, and $\geq 0.12 \mu \mathrm{g} / \mathrm{ml}$ resistance for meningitis isolates, while for nonmeningitis isolates, $\leq 2$ $\mu \mathrm{g} / \mathrm{ml}$ was susceptible, $4 \mu \mathrm{g} / \mathrm{ml}$ intermediate and $\geq 8$ $\mu \mathrm{g} / \mathrm{ml}$ resistant. ${ }^{3}$ According to this new standardization, frequency of penicillin resistance in pneumococci in infections other than meningitis will decrease, whereas resistance in CSF samples will increase. When we evaluate the samples in our study according to the CLSI criteria before 2008, there is no resistant strain. The resistant strains, which consist $14 \%$ according to new criteria were formerly in the intermediate group. With this new approach, penicillin use will increase in respiratory system infections and as a result, the frequency of bacteria such as resistant pneumococci, MRSA and C. difficile may decrease.

Especially regional spread of high level resistance should be carefully monitored and the first choice in the treatment should be penicillin $G$ in the absence of special indications. The result of resistance due to a change in PBPs of $S$. pneumoniae is an increase in penicillin MIC values, with a parallel increase in MIC values of other $\beta$-lactam antibiotics, which cause further decrease in our treatment options.

In a multicenter study in Turkey, 72 pneumococcal strains were isolated from the CSF in a period of five years, and high level resistance to penicillin $G$ was not detected with $E$ test, while intermediate susceptibility was detected in six strains $(8.3 \%)$. The rate of resistance was lower than the rate we determined in the present study. ${ }^{6}$ In the study by Tuncer et al., with 89 pneumococcal strains isolated from various clinical samples (16 from CSF), high level resistance to penicillin was detected in $4 \%$, and intermediate susceptibility in $15 \% .^{7}$ In a multicenter study from Istanbul and Adana city with 93 strains causing invasive pneumococcal disease (19 CSF samples) isolated between 2001-2004, intermediate susceptibility was detected in $31 \%$ and resistance in $8 \% .^{8}$ In a study from Turkey, 182 invasive pneumococcal isolates (32 and 150 isolates from cerebrospinal fluid and blood samples, respectively) were collected before the introduction of the 7-valent pneumococcal conjugate vaccine. In total, $50 \%$ CSF isolates were resistant to penicillin (MIC 
$\geq 0.12 \mu \mathrm{g} / \mathrm{l})$ according to $2012 \mathrm{CLSI}$ guidelines. Intermediate resistance was not observed. This rate of resistance was approximately three fold higher than the rate of present study. ${ }^{9}$

In a surveillance study of children in Kenya, Uganda, Tanzania and Ethiopia, a total of 442 pneumococcal strains, 302 from blood and 140 from CSF were isolated and no penicillin resistance was detected in any strains. ${ }^{10}$ In a surveillance program from Canada between the years 1991-1998, 1847 pneumococcal strains were studied ( 275 from CSF) and a statistically significant increase in resistance was found. Intermediate level resistance was detected as $8.4 \%$, high level resistance $1.1 \%$, and reduced susceptibility $9.5 \%$ in strains which had caused meningitis. ${ }^{11}$ In a study from Nepal in 2528 children with suspected invasive bacterial disease, meningitis were detected in $9.6 \%$ and 33 cases were designated as pneumococcal meningitis. $4 \%$ of all invasive isolates were penicillin resistant and intermediate susceptibility was detected in only one CSF isolate (MIC $0.5 \mu \mathrm{g} / \mathrm{ml}){ }^{12}$

In a study with Korean children between the years 1985-1996, 106 invasive pneumococcal infections (19\% meningitis), were evaluated and the first penicillin-resistant pneumococcal strain was isolated in 1989. Resistance rates have shown a steady increase and reached $89 \%$ in 1996 . Penicillin resistance was found in $45 \%$ of 20 cases with meningitis. ${ }^{13}$ High rates of resistance $(71.5 \%)$ was reported by PROTEKT study from South Korea. ${ }^{14}$ The pneumococcal resistance rates in our study is considerably lower than those reported by these studies.

In a sensitivity study of 11 years' duration on invasive pneumococcal strains from Portugal, the ratio of strains which were not sensitive to penicillin was $12 \%$ in 1994 , increasing to $23.2 \%$ in 2004 . Strains from CSF samples with intermediate and high level resistance was $16.2 \%, 2.9 \%$, respectively in 1994 and $18.8 \%, 1.3 \%$ respectively in $2004 .^{15}$

Analyzing the 72 invasive pneumococcal strains obtained from patients with meningitis during the years 1999 and 2009 in Brazil, the penicillin resistance rates for all ages was $23.6 \%$ and for children up to two years of age $39.4 \%$. Significant increases in the penicillin-resistance rates of invasive pneumococcal strains have been reported in Brazil. ${ }^{16}$

Pneumococcal infections, which may be seen in every age group, may result in severe sequel or death due to treatment failures caused by bacterial resistance, especially if they occur in life-threatening locations. Thus, knowledge on pneumococcal resistance patterns enables initiation of an appropriate treatment.

This study has some limitations. One of these limitations is absence of the determination of serotypes. The other limitation is the number of the strain was not high. Beside these limitations, this study will contribute new information about pneumococci resistance.

In conclusion, the new penicillin susceptibility breakpoints have increased the resistance rates in meningitis invasive pneumococcal infections. Penicillin therapy may be fail in meningitis if the rate of resistant isolates is high. The need for pneumococcal surveillance studies continues.

\section{REFERENCES}

1. Klugman KP. Pneumococcal resistance to antibiotics. Clin Microbiol Rev 1990; 3: 171-196.

2. Cetron MS, Jernigan DB, Breiman RF. Action Plan for DrugResistant Streptococcus pneumoniae. Emerg Infect Dis 1995: 64-65.

3. The Clinical and Laboratory Standards Institute: Performance Standards for Antimicrobial Susceptibility Testing; 18th Informational Supplement (M100-S18), CLSI, Wayne PA (2008).

4. WHO Report, Acute Respiratory Infections, 2009. Streptococcus pneumonia. Available from: URL: http://www.who.int/ vaccine_research/diseases/ari/en/index3.html

5. The Clinical and Laboratory Standards Institute: Performance Standards for Antimicrobial Susceptibility Testing; 17th Informational Suplement (M100-S17), CLSI, Wayne PA (2007).

6. Firat M, Ersoy Y, Esel D, et al. Antimicrobial susceptibility and serotype distribution of pneumococci strains isolated from meningitis patients. Bull Microbiol 2006; 40: 169-177.

7. Tuncer I, Arslan U, Fındık D, Ural O. Increasing penicillin resistance and resistance to some other antibiotics in Streptococcus pneumonia strains isolated from clinical specimens. ANKEM Derg 2005; 19:35-38.

8. Yalcin I, Gurler N, Alhan E, et al. Serotype distribution and antibiotic susceptibility of invasive Streptococcus disease isolates from children in Turkey, 2001-2004. Eur J Pediatr 2006; 165: 654-657.

9. Uludag Altun H, Hascelik G, Gur D, Koseoglu Eser O. Invasive pneumococci before the introduction of pneumococcal conjugate vaccine in Turkey: antimicrobial susceptibility, serotype distribution, and molecular identification of macrolide resistance. J Chemother 2014 Doi: http://dx.doi.org/10.1179/ 1973947814 Y.0000000176

10. Mudhune S, Wamae M. Report on invasive disease and meningitis due to Haemophilus influenzae and Streptococcus pneumonia from The Network for Surveillance of Pneumococcal diseases in the East African Region. Clin Infect Dis 2009; 48: 147-152.

11. Scheifele D, Halperin S, Pelletier L, et al. Reduced susceptibility to penicillin among pneumococci causing invasive infection in children - Canada, 1991 to 1998. Can J Infect Dis 2001; 12: 241-246. 
12. Shah AS, Deloria Knoll M, Sharma PR, et al. Invasive pneumococcal disease in Kanti Children's Hospital, Nepal, as observed by the South Asian Pneumococcal Alliance Network. Clin Infect Dis 2009; 48: 123-128.

13. Choi EH, Lee HJ. Clinical Outcome of Invasive Infections by Penicillin-Resistant Streptococcus pneumoniae in Korean Children. CID 1998; 26: 1346-1354.

14. Felmingham $D$, Reinert RR, Hirakata $Y$, Rodloff $A$. Increasing prevalence of antimicrobial resistance among isolates of Streptococcus pneumoniae from the PROTEKT surveil- lance study, and comparative in vitro activity of the ketolide, telithromycin. J Antimicrob Chemother 2002; 50: 25-37.

15. Dias R, Louro D, Canic M. Antimicrobial Susceptibility of Invasive Streptococcus pneumoniae Isolates in Portugal over an 11-Year Period. Antimicrob Agents Chemother 2006; 50: 2098-2105.

16. Alvares JR, Mantese OC, Paula A, et al. Prevalence of pneumococcal serotypes and resistance to antimicrobial agents in patients with meningitis: ten-year analysis. Braz J Infec Dis 2011; 15: 22-27. 